\title{
LIST OF TABLES AND FIGURES
}

\section{Tables}

2.1 Commitment to democratic values and attitudes

page 98

3.1 Effects of an education in democratic principles

3.2 Assessment of the effects of civic studies in relation to dependent variables (comparison between civics learners and non-civics learners)

3.3 Different levels of political knowledge acquired in civic studies courses (comparison between civic studies learners and non-civic studies learners)

\section{Figures}

I.1 The defending democracy and its different routes

3.1 A quantitative content analysis of the contents of Israeli civics education books

4.1 Pro-democratic civil society and the targets of its activities

4.2 The emergence of a 'pro-democratic civil society' in Israel 1950-2000 